\title{
Brokoli ve pırasada kükürt içeriği ve kükürtlü aminoasit miktarları arasındaki ilişkiler
}

\section{The correlation between the sulfur content and the amounts of sulfur-containing amino acids of leek and broccoli}

\author{
Nilgün MORDOĞAN ${ }^{1}$ iD , Seda ERDOĞAN BAYRAM ${ }^{2^{*}}$ iD Hakan ÇAKICI $^{1}$ iD, ibrahim DUMAN ${ }^{3}$ \\ ${ }^{1}$ Ege Üniversitesi, Ziraat Fakültesi, Toprak Bilimi ve Bitki Besleme Bölümü, İzmir, Türkiye \\ ${ }^{2}$ Ege Üniversitesi, Ziraat Fakültesi, Ege Agrolab Birimi, İzmir, Türkiye \\ ${ }^{3}$ Ege Üniversitesi, Ziraat Fakültesi, Bahçe Bitkileri Bölümü, İzmir, Türkiye
}

To cite this article:

Mordoğan, N., Erdoğan Bayram, S., Çakıcı, H. \& Duman, í. (2019). Brokoli ve pırasada kükürt içeriği ve kükürtlü aminoasit miktarları arasındaki ilişkiler. Harran Tarım ve Gıda Bilimleri Dergisi, 23(2): 263-276.

DOI: $10.29050 /$ harranziraat.510323

Address for Correspondence: Seda ERDOĞAN BAYRAM e-mail:

seda.erdogan@ege.edu.tr

Received Date:

08.01.2019

Accepted Date:

09.05.2019

(C) Copyright 2018 by Harran University Faculty of Agriculture. Available on-line at www.dergipark.gov.tr/harranziraat



öz

Bu çalışma, kışlık sebzelerden, yüksek kükürt içeriğine bağlı kükürtlü esensiyel amino asitlerden sistein ve methionini önemli düzeyde içerdiği bilinen brokoli ve pırasa bitkilerinde, kükürt ve diğer besin elementleri ile bu sebzelerin içerdikleri kükürtlü amino asit miktarları arasındaki ilişkileri ortaya koymak amaçlı yürütülmüştür. Buna yönelik; Ege Bölgesi sebze yetiştiriciliğinde önemli bir merkez durumunda olan İzmir ili Torbalı ilçesinden, brokoli ve pırasa yetiştiriciliğinin yaygın bir şekilde yapıldığı alanlardan toprak ve bitki örnekleri alınarak analiz edilmiştir. 0-30 cm derinlikten alınan toprak örneklerinin fiziksel kimyasal özellikleri ile verimlilik durumları saptanmış, bitki yapraklarında ise başta kükürt olmak üzere besin elementi içerikleri belirlenmiştir. Bitkilerin tüketilen kısımlarında; pırasada tüm bitki, brokolide ise baş kısımlarında; sistein ve methionin miktarları belirlenmiştir. Bitkilerin kükürtlü amino asit içerikleri ile toprak ve bitki örneklerinin kükürt ve diğer bitki besin maddesi içerikleri arasındaki ilişkiler ortaya koyulmuştur. Araştırma sonuçlarına göre; brokoli bitkisinin yaprak makro besin elementlerinden; $\mathrm{K}, \mathrm{Ca}$ ve $\mathrm{S}$ içerikleri ile sistein ve methionin içerikleri arasında pozitif ilişkiler belirlenirken pırasa bitkisinin incelenen yaprak besin elementleri ile sistein methionin içerikleri arasında herhangi bir ilişki belirlenmemiştir. Makro besin elementlerinin brokoli bitkisinin sistein ve methionin içeriklerini arttırması hususu, gübreleme uygulamalarında dikkate alınmalıdır.

Anahtar Kelimeler: Brokoli, Pırasa, Besin elementleri, Sistein, Methionin

\section{ABSTRACT}

This study was conducted with the aim of showing the correlation between the amounts of sulfur and other nutrient elements and sulfurous amino acids in broccoli and leeks, winter vegetables which are known to have a high sulfur content related to their significantly high content of the sulfurous amino acids cysteine and methionine. For this purpose, soil and plant samples were taken and analyzed from areas of Torbalı district in İzmir province, an important center of vegetable-producing in the Aegean Region of Turkey where broccoli and leeks are widely grown. The physical and chemical characteristics of samples taken from depths of 0-30 $\mathrm{cm}$ and their fertility were determined, as was the nutrient, particularly sulfur, content of the plant leaves. Amounts of cysteine and methionine were determined in the edible parts of the plant - in leeks, the whole plant, and in broccoli the heads. The relationship between the sulfurous amino acid content of the plants and the sulfur and other plant nutrient material contents of the soil and plant samples was determined. According to the results of the study, 
there was a positive correlation between the content of the leaf macro nutrient elements $\mathrm{K}, \mathrm{Ca}$ and $\mathrm{S}$ and the cysteine and methionine content of broccoli, but no correlation was found between the leaf nutrient elements examined and cysteine and methionine content in leeks. The fact that macro nutrient elements increase the cysteine and methionine content of broccoli plants should be taken into account when applying fertilizer.

Key Words: Broccoli, Leeks, Nutrient elements, Cysteine, Methionine

\section{Giriş}

Ülkemizde kışlık sebze olarak yoğun tüketilen pırasa ve brokoli bitkileri, özellikle Ege, Akdeniz ve Güney Marmara Bölgelerinde yaygın şekilde yetiştirilmektedir. Türkiye'de brokoli 25.481 da alanda 46.353 ton, pırasa ise 79.908 da alanda 231.678 ton üretim miktarına sahiptir. Brokoli üretiminde İzmir, 13.124 ton ile Antalya ve Mersin'in önünde ilk sırada yer alırken; pırasada 19.533 ton üretim ile Bursa, Mersin ve Samsun'dan sonra dördüncü sıradadır (TÜiK, 2016).

Brassicaceae familyası sebzeleri arasında yer alan Avrupa ve Amerika'da geniş alanlarda yetiştirilen ve sevilerek tüketilen brokolinin, son yıllarda ülkemizde de üretim ve tüketim miktarı hızla artmaktadır. Özellikle sağlık üzerine olan olumlu etkilerinin anlaşılması, brokoliye olan talebi arttırmaktadır (Eşiyok, 1996; Bozokalfa ve ark., 2003). Brokoli, içerdiği flavonoid ve glukozinolatlar gibi bioaktif bileşenlerin zengin bir kaynağı olup içerdiği indoller, sülforafan, betakaroten, selenyum, ditiyoltiyonlar, quersetin, lutein, $C$ ve $E$ vitaminleri açısından da insan sağlığı üzerinde çok faydalı bir sebzedir. Özel selülozik yapısı nedeniyle bağırsaklardaki zehirli maddeleri ve ağır metalleri uzaklaştırarak koruyucu bir etki göstermektedir (Anonim, 2002; Ünsal ve Hayoğlu, 2018).

Zambakgiller (liliaceae) familyasından olan pırasa, yılın her mevsiminde ve genellikle gövdesi için kısmen de yaprakları için yetiştirilen bir bitkidir. Kışlık sebze olarak kullanılan ve bütün bölgelerimizde üretilip tüketilen pırasa, özellikle kara ikliminin hüküm sürdüğü bölgelerimizde kışlık sebze tüketiminin çok önemli bir bölümünü oluşturmaktadır (MEGEP, 2013).

İnsan beslenmesinde önemli bir grup olan proteinler ve yapıtaşları amino asitleri içerdiği bilinen bu sebzelerin amino asit içeriklerinin belirlenmesi insan sağlığı açısından önem arz etmektedir. Bir makro besin elementi olan kükürt, bitkilerde düzenli büyüme, yüksek verim ve ürün kalitesi üzerine etkileri olan temel elementlerden biridir. Kükürdün bitkilerdeki en önemli fonksiyonu; sistin, sistein ve methionin gibi amino asitlerin temel yapı taşı olmasıdır. Bu amino asitler proteinlerin oluşumunda görev almakla birlikte, glütatyon, tiamin, biyotin, koenzim $A$ ve lipoik asit gibi önemli bileşiklerin de öncü maddesidir (Wielebski, 2015). Bu bağlamda kükürt; bitkilerde, sistein ve methionin aminoasit içeriğini etkileyerek ve azot metabolizmasında oynadığı rol ile verimi arttırmaktadır (Wielebski, 2015).

Vücutta biyokimyasal tepkimelerle diğer bileşiklerden sentez edilemedikleri için besinlerle günlük alınmaları gereken ve protein sentezinde kullanılan bazı aminoasitler; esansiyel aminoasitler olarak adlandırılırlar. Kükürtlü amino asitlerden sistein ve methionin de bu gruba girmektedir. Brassica ve Liliaceae familyasına ait bitkiler iyi birer protein kaynağı olup özellikle kükürt içeren gerekli bütün aminoasitleri içerirler (Salunkhe ve Kadam 1998). Bu bağlamda, araştırmanın konusunu oluşturan bitkilerde yüksek kükürt içeriğine bağlı artması beklenen kükürtlü aminoasitlerden sistein ve methioninin tespiti, pratikte insan beslenmesi açısından büyük önem taşımaktadır.

Bu çalışmada, brokoli ve pırasa yetiştiriciliğinin yaygın bir şekilde yapıldığı İzmir ili Torbalı ilçesinde başta kükürt olmak üzere toprak ve bitkide besin elementi içeriklerine bağlı kükürtlü aminoasit içeriklerinin belirlenmesi amaçlanmıştır. Ayrıca, söz konusu bu bitkilerin sistein ve methionin içerikleri ile kükürt ve diğer bitki besin maddeleri arasındaki ilişkiler ortaya konulmuştur. 


\section{Materyal ve Yöntem}

\section{Materyal}

Araştırma, 2012-2013 üretim döneminde, İzmir-Torbalı ilçesinde, brokoli ve pırasa yetiştiriciliği yapılan üretici bahçelerinde yürütülmüştür. Araştırma materyalini, bölgeyi temsil edecek şekilde seçilen $30^{\prime}$ ar adet pırasa ve brokoli bahçesinden alınan toprak ve bitki örnekleri oluşturmuştur.

\section{Yöntem}

Toprak örneklerinin alınması ve analiz yöntemleri

Eylül ayında, ekim öncesi, 0-30 cm derinlikten toprak örnekleri alınmış ve hava kurusu hale getirilerek $2 \mathrm{~mm}$ 'lik elekten geçirilip analize hazır hale getirilmiştir (Kacar, 1995). Toprak reaksiyonu ve suda çözünebilir toplam tuz, su ile doyurulmuş toprak çamurunda $\mathrm{pH}$ metre ve EC metre ile (Jackson, 1967; Anonim, 1993), kireç Scheibler kalsimetresi ile volümetrik (Kacar, 1995), organik madde titrimetrik (Schlichting ve Blume, 1966), bünye ise hidrometrik (Bouyoucos, 1951) yöntemler ile belirlenmiştir. Toplam N; modifiye Kjeldahl (Bremner, 1965) yöntemi ile alınabilir $P$ ise $\mathrm{NaHCO}_{3}$ ile ekstrakte edilen süzüklerde kolorimetrik (Olsen ve ark., 1954) yöntemle belirlenmiştir. $1 \mathrm{~N} \mathrm{NH}{ }_{4} \mathrm{OAc}$ ile ekstrakte edilen örneklerde; alınabilir K, Ca flame fotometre (EPPENDORF) (Pratt, 1965) ile; Mg, Fe, Zn, Mn, Cu ise 0.05 M DTPA+TEA ile ekstraksiyon sonrası elde edilen süzüklerde Atomik Absorbsiyon Spektrofotometre (VARIAN AA 240 FS) cihazı ile belirlenmiştir (Lindsay ve Norvell, 1978). Toprakların alınabilir $\mathrm{SO}_{4}{ }^{-2}$ içerikleri ise $\mathrm{KH}_{2} \mathrm{PO}_{4}$ ile ekstraksiyon sonrası spektrofotometre yardımıyla türbidimetrik olarak belirlenmiştir (Fox ve ark., 1964; Kacar, 2009).

Bitki örneklerinin alınması ve bitki analiz yöntemleri

Bitki örnekleri, brokoli bitkisinde baş oluşum döneminde, pırasa bitkisinde ise olgunluk öncesi (sap kalınlığı>1 cm) döneminde alınmıştır (Kacar ve İnal, 2008). Alınan örnekler, buz çantasında laboratuvara getirilerek çeşme ve saf sudan geçirildikten sonra bir kısmı uygun şekilde parçalanıp taze olarak vakumlanmış ve aminoasit belirlemeleri için $-20^{\circ} \mathrm{C}$ de saklanmıştır. Örneklerin kalan kısmı ise $65^{\circ} \mathrm{C}$ de sabit tartıma gelene kadar kurutulduktan sonra öğütülmüş ve analize hazır hale getirilmiştir (Kacar ve İnal, 2008).

Bitkilerin toplam $\mathrm{N}$ içerikleri, modifiye Kjeldahl yöntemine göre (Bremner, 1965) belirlenmiştir. Kuru yakma $\left(550^{\circ} \mathrm{C}^{\prime}\right.$ de kül haline getirilerek $3 \mathrm{~N}$ $\mathrm{HCl}$ ile çözündürülmüş) yöntemi ile elde edilen çözeltilerde; $P$, vanado molibda fosforik asit sarı renk yöntemi ile kolorimetrik; $\mathrm{K}$, Ca flame fotometrik; $\mathrm{Mg}, \mathrm{Fe}, \mathrm{Cu}, \mathrm{Zn}$ ve $\mathrm{Mn}$ miktarları ise AAS cihazında ölçülerek belirlenmiştir (Kacar, 1984). Bitki ekstraktlarında kükürt $\left(\mathrm{SO}_{4}-\mathrm{S}\right)$, türbidimetrik yöntemle belirlenmiştir (Kacar ve İnal, 2008).

Sebze örneklerinin kükürtlü amino asit belirlemeleri, Phenomenex EZ: faast (easy-fast amino acid sample testing kit, Phenomenex Company) hazır kitleri kullanılarak yapılmıştır. Kullanılan yöntem parametreleri: Inlet sıcaklığı: $250^{\circ} \mathrm{C}$, Detektör sıcaklığı: $320^{\circ} \mathrm{C}$, Kolon: length * Id $=10 \mathrm{~m} \cdot{ }^{*} 0,25 \mathrm{~mm}$., Oven: $110^{\circ} \mathrm{C}^{\prime}$ den $320^{\circ} \mathrm{C}^{\prime}$ ye $\left(32^{\circ} \mathrm{C} / \mathrm{min}\right.$ artışlarla), He: $60 \mathrm{kPa}$, Split oranı: 1:15 (Mustafa et al., 2007) olup çalışılan sebze grubu için yöntemde gerekli modifikasyonlar yapılmıştır.

\section{Bulgular ve Tartışma}

Toprakların bazı fiziksel ve kimyasal özellikleri

Bitki gruplarına göre alınan toprak örneklerinin bazı fiziksel ve kimyasal özelliklerine ilişkin maksimum, minimum ve ortalama değerler Çizelge 1'de verilmiştir.

Sonuçlarının değerlendirilmesinde uygulanan istatistik yöntemler

Her iki bitki çeşidinin yaprak besin element içeriklerine ilişkin verilerin normal dağılıma uygunluğu, IBM SPSS 25 Version paket programında Shapiro-Wilk testiyle belirlenmiştir. Test sonuçları, yaprak besin elementi içeriklerinin normal dağılıma uymadığını göstermiştir. Bu nedenle, yaprak besin elementi ile bitki amino ait (sistein ve methionin) içerikleri arasındaki ilişkiler parametrik olmayan test yöntemlerinden Spearman korelasyon testi ile belirlenmiştir. 
Çizelge 1. Brokoli ve pırasa topraklarının bazı fiziksel ve kimyasal özellikleri

Table 1. Some physical and chemical properties of broccoli and leek soils

\begin{tabular}{|c|c|c|c|c|c|c|c|c|}
\hline \multirow[b]{2}{*}{$\begin{array}{l}\text { Bitki } \\
\text { Plant }\end{array}$} & \multirow[b]{2}{*}{$\begin{array}{l}\text { Değişim } \\
\text { aralığı } \\
\text { Range }\end{array}$} & \multirow[b]{2}{*}{$\mathrm{pH}$} & \multicolumn{6}{|c|}{$\%$} \\
\hline & & & $\begin{array}{c}\text { Toplam tuz } \\
\text { Total salt }\end{array}$ & $\begin{array}{l}\text { Kireç } \\
\text { Lime }\end{array}$ & $\begin{array}{l}\text { Organik } \\
\text { madde } \\
\text { Organic } \\
\text { matter }\end{array}$ & $\begin{array}{l}\text { Kum } \\
\text { Sand }\end{array}$ & $\begin{array}{l}\text { Kil } \\
\text { Clay }\end{array}$ & $\begin{array}{l}\text { Mil } \\
\text { Silt }\end{array}$ \\
\hline \multirow{3}{*}{$\begin{array}{l}\overline{0} \\
\frac{0}{0} \\
\overline{0} \\
\overline{0}\end{array}$} & $\begin{array}{l}\text { Min. } \\
\text { Min. }\end{array}$ & 7.14 & 0.030 & 2.2 & 0.82 & 26.24 & 7.76 & 7.28 \\
\hline & $\begin{array}{l}\text { Maks. } \\
\text { Max. }\end{array}$ & 7.82 & 0.048 & 18.20 & 2.73 & 84.96 & 41.76 & 42.56 \\
\hline & $\begin{array}{l}\text { Ort. } \\
\text { Avg. }\end{array}$ & 7.51 & 0.040 & 8.80 & 1.90 & 64.05 & 28.95 & 32.80 \\
\hline \multirow{3}{*}{ 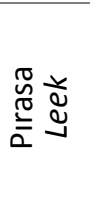 } & $\begin{array}{l}\text { Min. } \\
\text { Min. }\end{array}$ & 7.12 & 0.030 & 2.10 & 0.76 & 22.24 & 6.32 & 7.28 \\
\hline & $\begin{array}{l}\text { Maks. } \\
\text { Max. }\end{array}$ & 7.82 & 0.048 & 21.50 & 3.22 & 81.68 & 40.48 & 40.00 \\
\hline & $\begin{array}{l}\text { Ort. } \\
\text { Avg. }\end{array}$ & 7.50 & 0.040 & 8.31 & 1.84 & 61.86 & 28.96 & 29.09 \\
\hline
\end{tabular}

Çizelge 1 incelendiğinde, her iki bitki çeşidine ait toprakların, ortalama $\mathrm{pH}$ değerleri; 7,50 civarında olup hafif alkali $(7,4-7,8)$ reaksiyon göstermektedir (Kellog, 1952). Farklı araştırıcılar, brokoli ve pırasa yetiştiriciliğinde en uygun toprak pH'sının 6-7,5 arasında değişen nötr/hafif alkali tepkimeli topraklar olduğunu pırasa ve brokoli yetiştiriciliğinde asit topraklardan kaçınılması gerektiğini bildirmişlerdir (Yoldaş ve Eşiyok, 2004; MEGEP, 2013). Bu bağlamda; araştırma kapsamında incelenen yöre toprakları, $\mathrm{pH}$ yönü ile ele alınan her iki sebze çeşidi için uygundur. Ortalama suda çözünebilir \% toplam tuz içerikleri, her iki sebze çeşidine ait topraklarda aynı olup \% 0,040 bulunmuştur. Tuzluluk bakımından herhangi bir tehlike $(<\% 0.15)$ içermemektedir (U.S. Soil Survey Staff, 1951).

Brokoli ve pırasa yetiştirilen toprakların ortalama $\mathrm{CaCO}_{3}$ içerikleri sırasıyla; \% 8.80 ve \% 8.31 olarak saptanmıştır. Buna göre; her iki sebze çeşidinin yetiştirildiği yöre toprakları, kireççe zengindir (\% 5-10) (Evliya, 1960). Kireççe zengin topraklar, brokoli ve pırasa yetiştiriciliği için uygun değildir (Yoldaş ve Eşiyok, 2004; MEGEP, 2013). Toprakların ortalama organik madde kapsamları, brokoli topraklarında \% 1.90; pırasa topraklarında ise \% 1.84 olarak belirlenmiştir. Buna göre; her iki sebze çeşidine ait toprakların geneli, humusça fakir (<\% 2) durumdadır (Akalan, 1965). Elde edilen sonuçlar; organik maddece zengin topraklarda iyi gelişme gösterdiği bilinen (Yoldaş ve Eşiyok, 2004; MEGEP, 2013) sebzeler için yöre topraklarında organik gübre uygulamasının gerekliliğini ortaya koymaktadır. Bünyeleri; tın/kumlu-tın tespit edilen brokoli topraklarının; \% kum, kil ve mil içerikleri sırasıyla; 26.24-84.96, 7.76-41.76 ve 7.28-42.56 arasında değişirken, tın/killi-tın bünyeli tespit edilen pırasa topraklarının ise \% kum, kil ve mil içerikleri sırasıyla; 22.24-81.68, 6.32-40.48 ve 7.28-40.0 arasında değişim göstermiştir (Çizelge 1). Sebze tarımında ideal olduğu bildirilen geçirgenliği yüksek hafif bünyeli topraklara (Yoldaş ve Eşiyok, 2004; MEGEP, 2013) göre nispeten ağır bulunan yöre topraklarına organik gübre uygulanması, bünyenin olumsuz etkisini de azaltacaktır.

\section{Toprakların besin elementi içerikleri}

Araştırma alanı topraklarının toplam azot ile alınabilir bazı makro besin elementi içerikleri Çizelge 2'te verilmiştir.

Çizelge incelendiğinde; brokoli yetiştirilen toprakların toplam azot içeriklerinin \% 0.0430.155 , pırasa yetiştirilen toprakların ise \% 0.0440.158 arasında değiştiği görülmektedir. Buna göre; brokoli topraklarının yaklaşık olarak \% 7'si fakir (\%0.045-0,09), \% 43'ü orta (\% 0.05-0,10), \% 40 ' । iyi (\% 0.10-0.15) ve \% 10'u zengin (\% 0.15<) iken; pırasa topraklarının \% 10'u fakir, \% 63'ü orta, \% 20'si iyi, \% 7'si zengin sınıfında yer almıştır (FAO, 1990; Zengin, 2012).

Toprakların alınabilir fosfor içerikleri; brokoli topraklarında, $4.20-28.0 \mathrm{mg} \mathrm{kg}{ }^{-1}$, pırasa topraklarında ise $3.80-38.0 \mathrm{mg} \mathrm{kg}^{-1}$ arasında 
bulunmuştur. $\mathrm{Bu}$ değerlere göre; brokoli topraklarının yaklaşık \% 63' ü yeterli $\left(8-25 \mathrm{mg} \mathrm{kg}^{-}\right.$ $\left.{ }^{1}\right)$, \%7'si fazla ( $\left.>25 \mathrm{mg} \mathrm{kg}^{-1}\right), \% 30$ 'u az (<8 mg kg${ }^{-1}$ ) sınıfında yer alırken; pırasa topraklarının \% 53'ü yeterli, \% 7'si fazla, \% 40'ı az sınıfında (Zengin, 2012; FAO, 1990) bulunmuştur (Çizelge 2). Toprakların alınabilir fosfor içeriklerinin toprak pH'ları ile uyumlu olduğu görülmüştür.

Toprakların alınabilir potasyum içerikleri brokoli topraklarında $180-385 \mathrm{mg} \mathrm{kg}^{-1}$; pırasa topraklarında ise $140-422 \mathrm{mg} \mathrm{kg}{ }^{-1}$ arasında bulunmuştur (Çizelge 2). Buna göre; brokoli topraklarının yaklaşık olarak \% 73'ü yeterli (200$\left.300 \mathrm{mg} \mathrm{kg}^{-1}\right), \%$ 17'si yüksek (300-400 $\mathrm{mg} \mathrm{kg}^{-1}$ ) ve $\%$ 10'u düşük (150-200 mg kg $\left.{ }^{-1}\right)$; pırasa topraklarının ise \% 43'ü yeterli, \% 20'si yüksek, \% 7'si çok yüksek ve \% 10'u noksan düzeyde potasyum içermektedir (Fawzi ve El-Fouly, 1980).

Alınabilir kalsiyum içeriği 1860-4580 mg kg-1 arasında değişim gösteren brokoli topraklarının yaklaşık \% 53'ü çok fazla (>3571 $\mathrm{mg} \mathrm{kg}^{-1}$ ), \% 20'si fazla (2857-3571 mg kg-1), \% 13'ü iyi (2143-2857 $\left.\mathrm{mg} \mathrm{kg}{ }^{-1}\right)$ ve \% 13'ü normal (1428-2143 mg kg-1) düzeyde kalsiyum içermektedir. Pırasa topraklarının alınabilir kalsiyum içeriği ise 1350 $5100 \mathrm{mg} \mathrm{kg}^{-1}$ arasında değişim göstermiş olup (Çizelge 2) toprakların \% 40'ı çok fazla, \%3'ü fazla, \% 10'u iyi, \% 27'si normal ve \% 20 si fakir düzeyde bulunmuştur (Pratt, 1965).

Toprakların alınabilir magnezyum miktarları; brokoli topraklarında $82-380 \mathrm{mg} \mathrm{kg}{ }^{-1}$; pırasa topraklarında ise $85-310 \mathrm{mg} \mathrm{kg}^{-1}$ arasında bulunmuştur (Çizelge 2).

Pratt (1965)'e göre değerlendirildiğinde; brokoli topraklarının yaklaşık olarak \% 33'ü orta (80-160 $\left.\mathrm{mg} \mathrm{kg}^{-1}\right), \%$ 57'si yüksek (160-350 mg kg$\left.{ }^{1}\right)$, \% 10'u çok yüksek (>350 mg kg ${ }^{-1}$ ); pırasa topraklarının ise \% 53'ü orta, \% 47'si yüksek düzeyde magnezyum içermektedir.

Toprakların alınabilir kükürt $\left(\mathrm{SO}_{4}-\mathrm{S}\right)$ içerikleri brokoli topraklarında $1.22-15.2 \mathrm{mg} \mathrm{kg}^{-1}$, pırasa topraklarında ise 5.10 - $16.8 \mathrm{mg} \mathrm{kg}^{-1}$ arasında değişmiştir (Çizelge 2). Scott ve ark., (1983)'e göre; brokoli topraklarının \% 60'ı düşük (<10 mg $\mathrm{kg}^{-1}$ ), \% 40' । yeterli (> $10 \mathrm{mg} \mathrm{kg}{ }^{-1}$ ); pırasa topraklarının ise \% 40'ı düşük, \% 60'ı yeterli düzeyde alınabilir kükürt içermektedir.

Araştırma alanı topraklarının alınabilir bazı mikro besin element içerikleri Çizelge 3'de verilmiştir. Toprakların alınabilir demir içerikleri, brokoli topraklarında 3.80 - $52.6 \mathrm{mg} \mathrm{kg}^{-1}$; pırasa topraklarında ise $3.20-32.0 \mathrm{mg} \mathrm{kg}^{-1}$ arasında bulunmuştur (Çizelge 3). Buna göre brokoli topraklarının yaklaşık olarak \% 77'si orta (2.5-4.5 $\mathrm{mg} \mathrm{kg}{ }^{-1}$ ), \% 23'ü yüksek (>4.5 mg kg-1); pırasa topraklarının ise \% 40'ı orta, \% 60'ı yüksek düzeyde demir içermektedir (Zengin, 2012).

Toprakların alınabilir çinko içerikleri brokoli topraklarında, $0.25-2.65 \mathrm{mg} \mathrm{kg}{ }^{-1}$, pırasa topraklarında ise $0.25-2.55 \mathrm{mg} \mathrm{kg}^{-1}$ arasında değişim göstermiştir (Çizelge 3). Bu değerlere göre brokoli topraklarının yaklaşık \% 3'ü fazla (2.4-8.0 mg kg-1), \% 23'ü yeterli (0.7-2.4 mg kg-1) ve \% 73'ü az (0.2-0.7 $\left.\mathrm{mg} \mathrm{kg}^{-1}\right)$; pırasa topraklarının ise \% 13'ü fazla, \% 30'u yeterli ve \% 57'si az düzeyde çinko içermektedir (FAO, 1990; Zengin, 2012). Alınabilir bakır içeriği, brokoli yetiştirilen topraklarda; 3.60 - $14.6 \mathrm{mg} \mathrm{kg}^{-1}$; pırasa yetiştirilen topraklarda ise $4.20-15.8 \mathrm{mg} \mathrm{kg}^{-1}$ arasında değişim göstermiştir (Çizelge 3). İncelenen her iki bitki çeşidine ait toprakların tamamı yeterli düzeyde $\left(>0.2 \mathrm{mg} \mathrm{kg}^{-1}\right.$ ) bakır içermektedir (Zengin, 2012).

Toprakların alınabilir mangan içerikleri brokoli topraklarında $3.60-14.6 \mathrm{mg} \mathrm{kg}$; pırasa topraklarında ise $4.20-15.8 \mathrm{mg} \mathrm{kg}^{-1}$ arasında değişim göstermiştir (Çizelge 3). Lindsay ve Norvel (1978)'e göre değerlendirildiğinde her iki bitki çeşidine ait toprakların tamamı alınabilir $\mathrm{Mn}$ içerikleri yönüyle yeterli $\left(>1.2 \mathrm{mg} \mathrm{kg}{ }^{-1}\right)$ durumdadır. 
Çizelge 2 Brokoli ve pırasa topraklarına ilişkin alınabilir bazı makro besin element içerikleri

Table 2. Some available macro nutrient contents of broccoli and leek soils

\begin{tabular}{|c|c|c|c|c|c|c|c|c|c|c|c|c|}
\hline \multirow{3}{*}{$\begin{array}{l}\text { Örnek No } \\
\text { Sample No }\end{array}$} & \multicolumn{6}{|c|}{$\begin{array}{l}\text { Brokoli } \\
\text { Broccolli }\end{array}$} & \multicolumn{6}{|c|}{$\begin{array}{l}\text { Pırasa } \\
\text { Leek }\end{array}$} \\
\hline & \multicolumn{2}{|l|}{$\%$} & \multicolumn{3}{|c|}{$\begin{array}{l}\text { Alınabilir }\left(\mathrm{mg} \mathrm{kg}^{-1}\right) \\
\text { Available }\left(\mathrm{mg} \mathrm{kg}^{-1}\right)\end{array}$} & \multirow[b]{2}{*}{$\mathrm{SO}_{4}-\mathrm{S}$} & \multirow{2}{*}{$\begin{array}{c}\% \\
\text { Toplam N } \\
\text { Total N }\end{array}$} & \multicolumn{5}{|c|}{$\begin{array}{l}\text { Alınabilir }\left(\mathrm{mg} \mathrm{kg}^{-1}\right) \\
\text { Available }\left(\mathrm{mg} \mathrm{kg}^{-1}\right)\end{array}$} \\
\hline & $\begin{array}{c}\text { Toplam N } \\
\text { Total N }\end{array}$ & $P$ & $\mathrm{~K}$ & $\mathrm{Ca}$ & $\mathrm{Mg}$ & & & $P$ & K & $\mathrm{Ca}$ & $\mathrm{Mg}$ & $\mathrm{SO}_{4}-\mathrm{S}$ \\
\hline 1 & 0.046 & 21.0 & 215 & 3150 & 260 & 5.60 & 0.102 & 5.60 & 325 & 4510 & 98 & 16.2 \\
\hline 2 & 0.105 & 9.20 & 280 & 3810 & 120 & 12.0 & 0.088 & 4.20 & 390 & 4680 & 96 & 16.0 \\
\hline 3 & 0.085 & 7.10 & 265 & 3960 & 89 & 12.9 & 0.105 & 6.10 & 365 & 4440 & 101 & 12.8 \\
\hline 4 & 0.055 & 22.0 & 220 & 2920 & 215 & 4.20 & 0.089 & 7.20 & 295 & 4260 & 120 & 15.2 \\
\hline 5 & 0.068 & 4.60 & 360 & 4520 & 84 & 14.5 & 0.090 & 7.60 & 292 & 4340 & 136 & 12.5 \\
\hline 6 & 0.115 & 24.0 & 260 & 1980 & 285 & 6.20 & 0.101 & 12.0 & 215 & 1920 & 145 & 15.4 \\
\hline 7 & 0.120 & 22.0 & 315 & 2810 & 265 & 8.40 & 0.091 & 38.0 & 142 & 1420 & 310 & 7.20 \\
\hline 8 & 0.155 & 4.20 & 385 & 4580 & 82 & 15.2 & 0.091 & 10.0 & 270 & 4150 & 152 & 16.2 \\
\hline 9 & 0.142 & 17.0 & 251 & 3320 & 225 & 6.20 & 0.097 & 12.0 & 285 & 2810 & 148 & 10.2 \\
\hline 10 & 0.105 & 18.0 & 246 & 3210 & 260 & 7.10 & 0.044 & 18.0 & 182 & 1720 & 210 & 10.1 \\
\hline 11 & 0.152 & 15.0 & 264 & 3840 & 180 & 4.60 & 0.090 & 12.0 & 235 & 2150 & 138 & 5.10 \\
\hline 12 & 0.128 & 28.0 & 185 & 1860 & 380 & 1.40 & 0.090 & 4.20 & 422 & 4910 & 85 & 16.8 \\
\hline 13 & 0.102 & 24.0 & 210 & 1960 & 340 & 2.60 & 0.106 & 14.0 & 218 & 1760 & 196 & 8.20 \\
\hline 14 & 0.105 & 26.0 & 191 & 1920 & 360 & 1.90 & 0.078 & 16.0 & 212 & 1810 & 190 & 8.10 \\
\hline 15 & 0.142 & 24.0 & 205 & 2200 & 315 & 2.40 & 0.101 & 18.0 & 185 & 1620 & 260 & 5.40 \\
\hline 16 & 0.098 & 20.0 & 200 & 2680 & 300 & 2.60 & 0.094 & 14.0 & 234 & 2665 & 195 & 11.2 \\
\hline 17 & 0.082 & 7.80 & 220 & 3420 & 240 & 8.20 & 0.103 & 7.20 & 196 & 4880 & 105 & 12.6 \\
\hline 18 & 0.092 & 8.60 & 260 & 4050 & 210 & 12.6 & 0.045 & 9.20 & 241 & 1785 & 220 & 10.3 \\
\hline 19 & 0.096 & 16.0 & 255 & 3540 & 190 & 3.50 & 0.093 & 3.80 & 395 & 5100 & 88 & 15.6 \\
\hline 20 & 0.098 & 6.20 & 322 & 4450 & 84 & 13.2 & 0.094 & 17.0 & 185 & 1380 & 260 & 6.40 \\
\hline 21 & 0.102 & 7.60 & 280 & 4310 & 88 & 14.1 & 0.194 & 17.0 & 260 & 1615 & 190 & 8.50 \\
\hline 22 & 0.122 & 5.80 & 294 & 4540 & 86 & 14.8 & 0.095 & 6.20 & 320 & 4260 & 112 & 12.1 \\
\hline 23 & 0.098 & 6.40 & 222 & 4210 & 92 & 12.1 & 0.158 & 3.80 & 360 & 4600 & 94 & 14.2 \\
\hline 24 & 0.152 & 12.0 & 265 & 4150 & 186 & 11.4 & 0.091 & 18.0 & 265 & 1580 & 188 & 12.7 \\
\hline 25 & 0.043 & 8.60 & 285 & 3940 & 165 & 11.9 & 0.078 & 4.60 & 412 & 4840 & 92 & 6.30 \\
\hline 26 & 0.075 & 10.0 & 215 & 3630 & 192 & 6.20 & 0.069 & 5.20 & 274 & 2950 & 136 & 7.70 \\
\hline 27 & 0.098 & 26.0 & 180 & 2650 & 395 & 1.22 & 0.098 & 26.0 & 146 & 1410 & 255 & 8.30 \\
\hline 28 & 0.092 & 9.60 & 265 & 3860 & 110 & 7.10 & 0.080 & 18.0 & 165 & 1350 & 220 & 7.60 \\
\hline 29 & 0.090 & 10.1 & 245 & 3750 & 160 & 5.60 & 0.097 & 24.0 & 140 & 1420 & 280 & 10.4 \\
\hline 30 & 0.105 & 5.80 & 375 & 4250 & 86 & 14.4 & 0.048 & 21.0 & 172 & 1360 & 215 & 16.8 \\
\hline $\begin{array}{l}\text { Min. } \\
\text { Min. }\end{array}$ & 0.043 & 4.20 & 180 & 1860 & 82 & 1.22 & 0.044 & 3.80 & 140 & 1350 & 85 & 5.10 \\
\hline $\begin{array}{l}\text { Maks. } \\
\text { Max. }\end{array}$ & 0.155 & 28.0 & 385 & 4580 & 380 & 15.2 & 0.158 & 38.0 & 422 & 5100 & 310 & 16.8 \\
\hline $\begin{array}{l}\text { Ort. } \\
\text { Avg. }\end{array}$ & 0.102 & 14.2 & 258 & 3449 & 202 & 8.10 & 0.093 & 12.7 & 260 & 2923 & 168 & 11.2 \\
\hline $\begin{array}{c}\text { St. Sapma } \\
\text { St. Deviation }\end{array}$ & 0.029 & 7.71 & 53.6 & 859.0 & 98.5 & 4.68 & 0.028 & 7.98 & 83.8 & 1442 & 64.9 & 3.73 \\
\hline $\begin{array}{l}\text { Çarpıklık } \\
\text { kats. } \\
\text { Skewness } \\
\text { coef. }\end{array}$ & -0.030 & 0.36 & 0.80 & -0.573 & 0.37 & 0.08 & 1.554 & 1.20 & 0.43 & 0.291 & 0.47 & 0.05 \\
\hline $\begin{array}{c}\text { Basıklık kats. } \\
\text { Kurtosis } \\
\text { coef. }\end{array}$ & -0.041 & -1.43 & 0.31 & -0.836 & $\begin{array}{c}- \\
0.95\end{array}$ & -1.48 & 5.768 & 1.98 & $\begin{array}{c}- \\
0.81\end{array}$ & -1.782 & $\begin{array}{c}- \\
0.83\end{array}$ & -1.31 \\
\hline
\end{tabular}


Çizelge 3 Brokoli ve pırasa topraklarına ilişkin alınabilir bazı mikro besin element içerikleri Table 3. Some micro nutrient contents of broccoli and leek soils

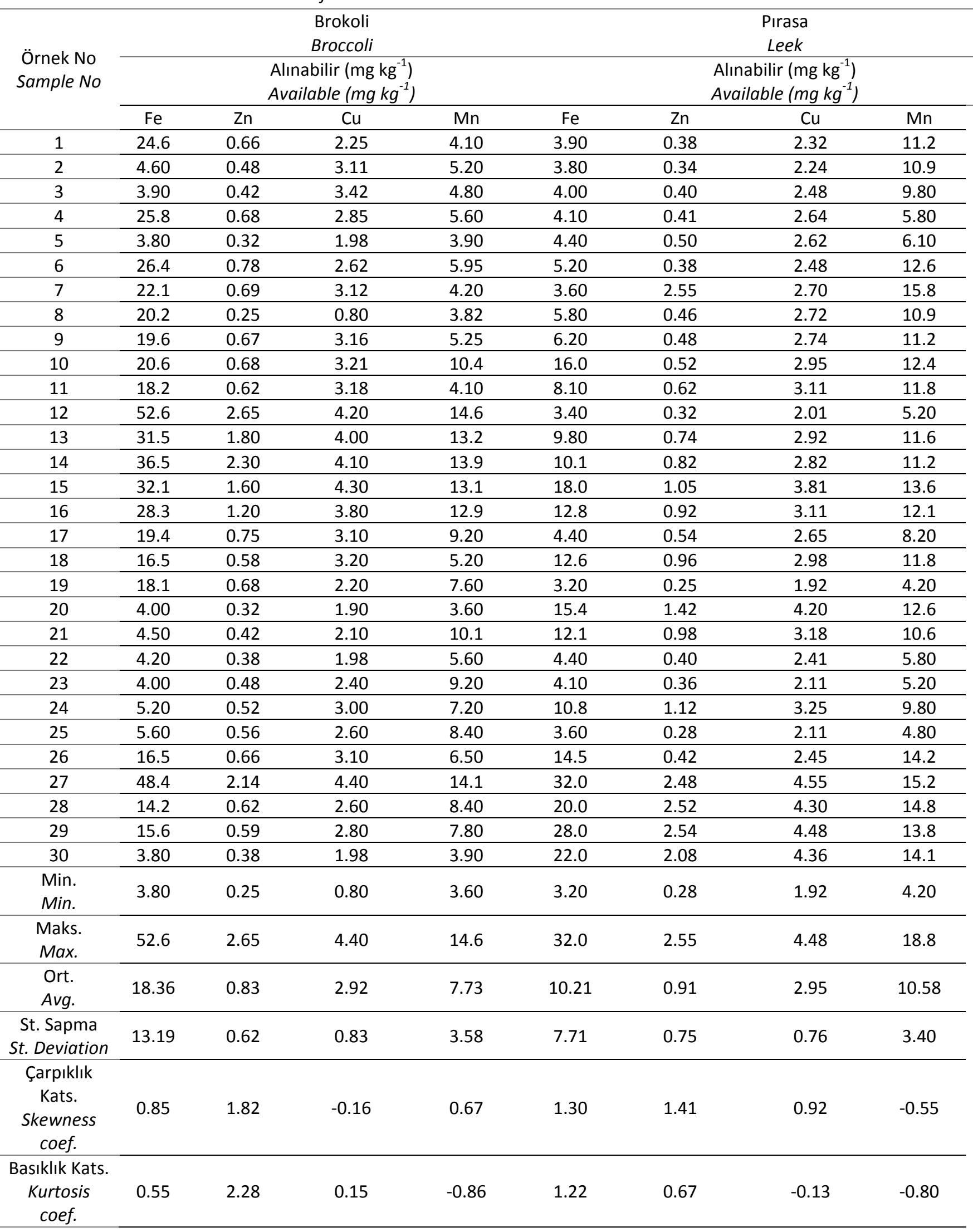

\section{Yaprakların besin elementi içerikleri}

Brokoli ve pırasa bitkilerinden alınan yaprakların bazı makro besin elementi içerikleri Çizelge 4'te verilmiştir.

Brokoli bitkisine ait yaprak azot içerikleri; \% 2.88 - 5.03 aralığında belirlenmiştir (Çizelge 4).
Brokoli bitkisinin baş oluşum dönemi için farklı araştırıcılar tarafından bildirilen, yaprakta azot yeterlilik düzeylerine göre (Reuter ve Robinson, 1986; Kacar ve İnal, 2008; Kacar, 2014) incelenen brokoli bahçelerinin yaklaşık \% 93'ü azotça yeterli (\% 3.20 - 5.50) bulunmuştur. Pırasa yaprak 
örneklerinin azot içerikleri ise \% 4.34 - 5.42 arasında değişmiştir. Pırasa bitkisi yapraklarında olgunluk dönemi için Kacar ve İnal (2008) yapraklarda azotun yeterli düzeylerini \%4.50-5.50; Reuter ve Robinson (1986) ise \% 4.57 olarak bildirmişlerdir. Buna göre incelenen pırasa bahçelerinin yaklaşık \% 83'ünün azotça yeterli beslendiği saptanmıştır. Her iki bitki çeşidinin de azot içerikleri, ait olduğu toprakların azot içerikleriyle de paralellik göstermiştir

Brokoli bitkisine ait yaprakların fosfor içerikleri; \% $0.25-0.97$ arasında belirlenmiştir (Çizelge 4). Brokoli bitkisi baş oluşum döneminde Reuter ve Robinson (1986), yapraklarda yeterli fosfor miktarlarının \% 0.30 - 0.70; Kacar ve İnal, 2008; Kacar, 2014 ise \% $0.30-0.75$ arasında olduğunu bildirmişlerdir. Bildirilen değerlere göre yöre bahçelerinin \% 90'ı fosforca yeterli durumdadır. Pırasa yapraklarının fosfor içerikleri ise \% 0.28 0.49 arasında değişim göstermiştir. Kacar ve Inal (2008), olgunluk döneminde pırasa bitkisi yapraklarında yeterli fosfor düzeyinin \% 0.30 0.45 arasında olduğunu bildirmişlerdir. Buna göre incelenen pırasa bahçelerinin yaklaşık \% 93'ünün fosforca yeterli durumda olduğu görülmüştür.

Brokoli bitkilerine ait yaprak potasyum içerikleri \%2.15 - 4.02 arasında bulunmuştur (Çizelge 4).

Brokoli bitkisinin baş oluşum dönemi için farklı araştırıcılar tarafından bildirilen, yaprakta potasyumun yeterli (\% 2.0 - 4.0) miktarlarına göre; incelenen bahçelerin tamamı, potasyumca yeterlidir (Reuter and Robinson, 1986; Kacar ve Inal, 2008; Kacar, 2014). Pırasa yapraklarının potasyum içerikleri ise \% 3.29-5.58 arasında değişmiştir. Pırasa bitkisi yapraklarında olgunluk dönemi için farklı araştırıcılar (Kacar ve İnal, 2008; Kacar, 2014) tarafından bildirilen yaprakta potasyumun yeterli (\% 3.5-5.0) düzeylerine göre, incelenen pırasa bahçelerinin yaklaşık \% 83'ünün potasyumca yeterli durumda olduğu görülmektedir.

Brokoli yapraklarının kalsiyum içerikleri \% 1.37 - 2.79 arasında belirlenmiştir (Çizelge 4). Reuter and Robinson (1986), brokoli bitkisi baş oluşum döneminde yaprakta kalsiyumun yeterli düzeyini \% 1.0 - 2.50; Kacar ve İnal (2008) ve Kacar (2014) ise \% $1.20 \quad-2.50$ arasında olduğunu bildirmişlerdir. Farklı araştırıcılar tarafından bildirilen yaprakta kalsiyum yeterlilik düzeylerine göre, incelenen brokoli bahçelerinin yaklaşık \%93'ü kalsiyumca yeterli düzeyde bulunmuştur. Yörede incelenen pırasa bahçelerine ait yaprakların kalsiyum içerikleri ise \% 1.36 - 2.66 arasında değişim göstermiştir (Çizelge 4). Reuter ve Robinson (1986), pırasa bitkisi yapraklarında olgunluk dönemi için yaprakta kalsiyumun yeterli miktarlarını \% 1.60 olarak bidirirken; Kacar ve İnal (2008) ile Kacar (2014) ise \% 1.5 - 2.2 arasında değişim gösterdiğini bildirmişlerdir. Buna göre; incelenen pırasa bahçelerinin tamamının kalsiyumca yeterli durumda olduğu saptanmıştır.

Brokoli yapraklarının magnezyum içerikleri, \% $0.20-0.80$ arasında tespit edilmiştir (Çizelge 4). Incelenen brokoli bahçelerinin yaklaşık \% 83'ünün, baş oluşum dönemi için bildirilen yaprakta magnezyumun yeterli miktarlarına (\% 0.23 - 0.75) göre (Kacar, 2014) magnezyum beslenmesi yönü ile yeterli olduğu görülmektedir. Pırasa yapraklarının magnezyum içerikleri ise \% 0.29 - 0.45 arasında değişmektedir. Pırasa bitkisi yapraklarında olgunluk dönemi için farklı araştırıcılar tarafından bildirilen yaprakta yeterli magnezyum miktarlarına (\% 0.25 - 0.40) göre (Kacar ve İnal, 2008; Kacar, 2014) incelenen pırasa bahçelerinin tamamı magnezyumca yeterli bulunmuştur. 
Çizelge 4. Brokoli ve pırasa yapraklarına ilişkin bazı makro besin elementi içerikleri

Table 4. Some macro nutrient contents of broccoli and leek leaves

\begin{tabular}{|c|c|c|c|c|c|c|c|c|c|c|c|c|}
\hline \multirow{3}{*}{$\begin{array}{l}\text { Örnek No } \\
\text { Sample No }\end{array}$} & \multicolumn{6}{|c|}{$\begin{array}{l}\text { Brokoli } \\
\text { Broccoli }\end{array}$} & \multicolumn{6}{|c|}{$\begin{array}{c}\text { Pırasa } \\
\text { Leek }\end{array}$} \\
\hline & \multicolumn{12}{|c|}{$\%$} \\
\hline & $\mathrm{N}$ & $P$ & $\mathrm{~K}$ & $\mathrm{Ca}$ & $\mathrm{Mg}$ & $\mathrm{SO}_{4}-\mathrm{S}$ & $\mathrm{N}$ & $P$ & $K$ & $\mathrm{Ca}$ & $\mathrm{Mg}$ & $\mathrm{SO}_{4}-\mathrm{S}$ \\
\hline 1 & 3.16 & 0.73 & 3.08 & 2.15 & 0.32 & 0.28 & 5.14 & 0.33 & 4.00 & 2.42 & 0.32 & 0.80 \\
\hline 2 & 5.03 & 0.70 & 3.55 & 2.74 & 0.30 & 0.47 & 5.01 & 0.35 & 3.91 & 2.45 & 0.32 & 0.80 \\
\hline 3 & 3.45 & 0.40 & 3.78 & 2.72 & 0.28 & 0.48 & 5.25 & 0.35 & 4.00 & 2.52 & 0.38 & 0.75 \\
\hline 4 & 3.62 & 0.73 & 3.11 & 2.05 & 0.40 & 0.26 & 4.45 & 0.33 & 4.00 & 2.32 & 0.40 & 0.90 \\
\hline 5 & 3.86 & 0.28 & 3.85 & 2.23 & 0.22 & 0.46 & 4.94 & 0.38 & 4.23 & 2.25 & 0.42 & 0.80 \\
\hline 6 & 4.16 & 0.80 & 3.20 & 1.53 & 0.45 & 0.28 & 5.03 & 0.45 & 3.82 & 1.98 & 0.35 & 0.80 \\
\hline 7 & 4.49 & 0.69 & 3.50 & 2.01 & 0.47 & 0.32 & 4.79 & 0.49 & 3.32 & 1.77 & 0.42 & 0.45 \\
\hline 8 & 4.91 & 0.26 & 4.02 & 2.79 & 0.20 & 0.52 & 4.52 & 0.40 & 3.61 & 2.30 & 0.45 & 0.90 \\
\hline 9 & 4.82 & 0.86 & 3.60 & 2.22 & 0.65 & 0.24 & 4.85 & 0.40 & 4.42 & 1.63 & 0.35 & 0.60 \\
\hline 10 & 4.05 & 0.87 & 3.60 & 2.20 & 0.76 & 0.30 & 4.41 & 0.47 & 3.61 & 1.36 & 0.36 & 0.65 \\
\hline 11 & 4.51 & 0.84 & 3.60 & 2.42 & 0.60 & 0.29 & 4.50 & 0.34 & 4.42 & 1.60 & 0.40 & 0.45 \\
\hline 12 & 4.33 & 0.97 & 2.80 & 1.37 & 0.80 & 0.25 & 4.50 & 0.30 & 3.42 & 2.66 & 0.30 & 0.95 \\
\hline 13 & 4.26 & 0.81 & 3.22 & 1.51 & 0.77 & 0.26 & 5.28 & 0.41 & 3.92 & 1.69 & 0.37 & 0.40 \\
\hline 14 & 4.62 & 0.86 & 2.93 & 1.40 & 0.80 & 0.28 & 4.57 & 0.36 & 3.71 & 1.84 & 0.33 & 0.47 \\
\hline 15 & 4.42 & 0.79 & 3.10 & 1.63 & 0.73 & 0.35 & 5.22 & 0.39 & 3.63 & 1.56 & 0.33 & 0.40 \\
\hline 16 & 3.72 & 0.76 & 3.03 & 1.83 & 0.70 & 0.24 & 4.71 & 0.36 & 3.91 & 1.74 & 0.40 & 0.70 \\
\hline 17 & 3.79 & 0.48 & 3.12 & 2.23 & 0.80 & 0.46 & 5.15 & 0.38 & 4.13 & 2.31 & 0.40 & 0.82 \\
\hline 18 & 3.72 & 0.70 & 3.35 & 2.76 & 0.22 & 0.50 & 4.34 & 0.40 & 4.39 & 1.52 & 0.32 & 0.80 \\
\hline 19 & 3.70 & 0.73 & 3.40 & 2.22 & 0.25 & 0.27 & 4.66 & 0.28 & 4.89 & 2.53 & 0.30 & 0.60 \\
\hline 20 & 3.79 & 0.44 & 3.70 & 2.25 & 0.22 & 0.54 & 4.71 & 0.44 & 3.90 & 1.58 & 0.40 & 0.44 \\
\hline 21 & 3.83 & 0.50 & 3.48 & 2.32 & 0.75 & 0.53 & 5.41 & 0.40 & 4.49 & 1.92 & 0.35 & 0.43 \\
\hline 22 & 4.60 & 0.49 & 3.65 & 2.79 & 0.20 & 0.54 & 4.73 & 0.39 & 4.17 & 2.57 & 0.30 & 0.40 \\
\hline 23 & 3.79 & 0.50 & 3.13 & 2.27 & 0.60 & 0.42 & 5.42 & 0.28 & 4.39 & 2.45 & 0.30 & 0.80 \\
\hline 24 & 4.72 & 0.85 & 3.70 & 2.24 & 0.62 & 0.45 & 4.53 & 0.45 & 4.07 & 1.58 & 0.30 & 0.85 \\
\hline 25 & 2.88 & 0.76 & 3.77 & 2.29 & 0.49 & 0.44 & 4.75 & 0.36 & 5.58 & 2.49 & 0.29 & 0.41 \\
\hline 26 & 3.20 & 0.69 & 2.15 & 2.33 & 0.70 & 0.21 & 4.46 & 0.39 & 3.71 & 1.87 & 0.30 & 0.40 \\
\hline 27 & 3.79 & 0.84 & 2.92 & 1.72 & 0.80 & 0.29 & 4.92 & 0.44 & 3.29 & 1.66 & 0.40 & 0.40 \\
\hline 28 & 3.90 & 0.54 & 3.42 & 2.52 & 0.78 & 0.25 & 4.50 & 0.44 & 3.39 & 1.79 & 0.38 & 0.42 \\
\hline 29 & 3.86 & 0.62 & 3.74 & 2.38 & 0.49 & 0.24 & 4.85 & 0.42 & 3.49 & 1.68 & 0.39 & 0.44 \\
\hline 30 & 4.06 & 0.25 & 3.84 & 2.75 & 0.20 & 0.56 & 4.43 & 0.45 & 3.60 & 1.88 & 0.40 & 0.60 \\
\hline $\begin{array}{l}\text { Min. } \\
\text { Min. }\end{array}$ & 2.88 & 0.25 & 2.15 & 1.37 & 0.20 & 0.21 & 4.34 & 0.28 & 3.29 & 1.36 & 0.29 & 0.40 \\
\hline $\begin{array}{l}\text { Maks. } \\
\text { Max. }\end{array}$ & 5.03 & 0.97 & 4.02 & 2.79 & 0.80 & 0.56 & 5.42 & 0.49 & 5.58 & 2.66 & 0.45 & 0.90 \\
\hline $\begin{array}{l}\text { Ort. } \\
\text { Avg. }\end{array}$ & 4.03 & 0.66 & 3.38 & 2.20 & 0.52 & 0.37 & 4.80 & 0.39 & 3.98 & 2.00 & 0.36 & 0.62 \\
\hline $\begin{array}{l}\text { St. Sapma } \\
\text { St. Error }\end{array}$ & 0.53 & 0.20 & 0.40 & 0.42 & 0.23 & 0.12 & 0.32 & 0.05 & 0.49 & 0.39 & 0.05 & 0.19 \\
\hline $\begin{array}{l}\text { Çarpıklık } \\
\text { Kats. } \\
\text { Skewness } \\
\text { coef. }\end{array}$ & -0.02 & -0.69 & -0.95 & -0.45 & -0.18 & 0.33 & 0.46 & -0.23 & 1.22 & 0.25 & 0.07 & 0.16 \\
\hline $\begin{array}{l}\text { Basıklık Kats. } \\
\text { Kurtosis } \\
\text { coef. }\end{array}$ & -0.40 & -0.49 & 1.57 & -0.50 & -1.61 & -1.58 & -0.96 & -0.40 & 2.56 & -1.47 & -1.25 & -1.65 \\
\hline
\end{tabular}

Brokoli yaprakları kükürt $\left(\mathrm{SO}_{4}-\mathrm{S}\right)$ içerikleri, \% 0.20-0.57 arasında bulunmuştur (Çizelge 4). Bulgularımız, brokoli bitkisi yapraklarında, baş oluşum dönemi için bildirilen yeterli kükürt düzeylerine (\% 0.30 - 0.75) göre (Kacar ve İnal, 2008; Kacar, 2014), yöredeki brokoli bahçelerinin \%50'si kükürt beslenmesi yönü ile yetersizdir. Pırasa yapraklarının kükürt $\left(\mathrm{SO}_{4}-\mathrm{S}\right)$ içerikleri ise \% $0.40-0.90$ arasında tespit edilmiştir. Çeşitli araştırıcılar tarafından pırasa bitkisi yapraklarında kükürdün yeterli düzeyi, \% $0.30-0.75$ olarak bildirilmiştir (Kacar ve İnal, 2008; Kacar, 2014). Bildirilen yeterlilik düzeylerine göre, incelenen pırasa bahçelerinin yaklaşık \% 43'ünün kükürtçe yetersiz beslendiği görülmüştür. İncelenen her iki bitki çeşidinin yapraklarında belirlenen $\mathrm{N}, \mathrm{P}, \mathrm{K}, \mathrm{Ca}$, $\mathrm{Mg}$ ve $\mathrm{S}$ içerikleri, aynı elementlerin topraklardaki alınabilir miktarları ile uyum göstermektedir. 
Çizelge 5 Brokoli ve pırasa yapraklarına ilişkin bazı mikro besin elementi içerikleri Table 5. Some micro nutrient contents of broccoli and leek leaves

\begin{tabular}{|c|c|c|c|c|c|c|c|c|}
\hline \multirow{3}{*}{$\begin{array}{l}\text { Örnek No } \\
\text { Sample No }\end{array}$} & \multicolumn{4}{|c|}{$\begin{array}{l}\text { Brokoli } \\
\text { Broccoli }\end{array}$} & \multicolumn{4}{|c|}{$\begin{array}{l}\text { Pırasa } \\
\text { Leek }\end{array}$} \\
\hline & \multicolumn{8}{|c|}{$\mathrm{mg} \mathrm{kg}^{-1}$} \\
\hline & $\mathrm{Fe}$ & $\mathrm{Zn}$ & $\mathrm{Cu}$ & $\mathrm{Mn}$ & $\mathrm{Fe}$ & $\mathrm{Zn}$ & $\mathrm{Cu}$ & $\mathrm{Mn}$ \\
\hline 1 & 140 & 33.0 & 5.10 & 27.0 & 58.0 & 22.0 & 20.0 & 102 \\
\hline 2 & 134 & 28.0 & 4.40 & 58.0 & 52.0 & 22.0 & 20.0 & 105 \\
\hline 3 & 67.0 & 28.0 & 4.60 & 32.0 & 55.0 & 24.0 & 21.0 & 148 \\
\hline 4 & 115 & 27.0 & 4.80 & 26.0 & 56.0 & 51.0 & 21.0 & 150 \\
\hline 5 & 66.0 & 28.0 & 4.90 & 28.0 & 59.0 & 24.0 & 26.0 & 149 \\
\hline 6 & 149 & 86.0 & 8.30 & 34.0 & 102 & 24.0 & 21.0 & 144 \\
\hline 7 & 131 & 31.0 & 6.30 & 28.0 & 58.0 & 94.0 & 30.0 & 165 \\
\hline 8 & 68.0 & 31.0 & 4.60 & 29.0 & 118 & 22.0 & 24.0 & 150 \\
\hline 9 & 177 & 35.0 & 9.00 & 38.0 & 124 & 27.0 & 21.0 & 155 \\
\hline 10 & 168 & 35.0 & 10.4 & 67.0 & 123 & 22.0 & 26.0 & 150 \\
\hline 11 & 145 & 32.0 & 7.00 & 35.0 & 135 & 22.0 & 26.0 & 143 \\
\hline 12 & 198 & 102 & 16.4 & 73.0 & 50.0 & 22.0 & 23.0 & 109 \\
\hline 13 & 188 & 98.0 & 10.4 & 76.0 & 124 & 71.0 & 20.0 & 148 \\
\hline 14 & 176 & 123 & 10.1 & 78.0 & 129 & 73.0 & 24.0 & 146 \\
\hline 15 & 180 & 96.0 & 8.00 & 77.0 & 207 & 76.0 & 29.0 & 108 \\
\hline 16 & 102 & 92.0 & 5.10 & 72.0 & 170 & 72.0 & 25.0 & 148 \\
\hline 17 & 155 & 27.0 & 7.40 & 63.0 & 58.0 & 27.0 & 26.0 & 163 \\
\hline 18 & 118 & 29.0 & 5.90 & 48.0 & 126 & 59.0 & 24.0 & 150 \\
\hline 19 & 124 & 32.0 & 6.30 & 43.0 & 56.0 & 22.0 & 26.0 & 106 \\
\hline 20 & 65.0 & 31.0 & 5.10 & 38.0 & 240 & 61.0 & 29.0 & 145 \\
\hline 21 & 63.0 & 36.0 & 7.20 & 61.0 & 134 & 83.0 & 27.0 & 159 \\
\hline 22 & 65.0 & 34.0 & 9.70 & 37.0 & 57.0 & 28.0 & 26.0 & 180 \\
\hline 23 & 141 & 27.0 & 7.10 & 36.0 & 55.0 & 24.0 & 29.0 & 104 \\
\hline 24 & 124 & 31.0 & 7.70 & 34.0 & 125 & 23.0 & 35.0 & 138 \\
\hline 25 & 129 & 31.0 & 5.00 & 36.0 & 51.0 & 28.0 & 26.0 & 100 \\
\hline 26 & 107 & 28.0 & 7.80 & 36.0 & 131 & 26.0 & 31.0 & 146 \\
\hline 27 & 190 & 124 & 15.5 & 61.0 & 298 & 81.0 & 33.0 & 170 \\
\hline 28 & 140 & 30 & 5.00 & 38.0 & 277 & 91.0 & 34.0 & 151 \\
\hline 29 & 126 & 27 & 5.50 & 34.0 & 268 & 85.0 & 30.0 & 150 \\
\hline 30 & 66.0 & 32 & 4.90 & 33.0 & 240 & 95.0 & 36.0 & 197 \\
\hline $\begin{array}{l}\text { Min. } \\
\text { Min. }\end{array}$ & 63.0 & 27 & 4.40 & 26.0 & 50.0 & 22.0 & 20.0 & 100 \\
\hline $\begin{array}{l}\text { Maks. } \\
\text { Max. }\end{array}$ & 198 & 124 & 16.40 & 78.0 & 298 & 95.0 & 36.0 & 197 \\
\hline $\begin{array}{l}\text { Ort. } \\
\text { Avg. }\end{array}$ & 127 & 48 & 7.30 & 46.0 & 125 & 47.0 & 26.0 & 143 \\
\hline $\begin{array}{l}\text { St. Sapma } \\
\text { St. } \\
\text { Deviation }\end{array}$ & 42.3 & 32 & 3.00 & 17.4 & 76.0 & 27.8 & 4.57 & 24.2 \\
\hline $\begin{array}{l}\text { Çarpıklık } \\
\text { Kats. } \\
\text { Skewness } \\
\text { Coef. }\end{array}$ & -0.16 & 1.5 & 1.67 & 0.73 & 0.96 & 0.56 & 0.45 & -0.32 \\
\hline $\begin{array}{l}\text { Basıklık } \\
\text { Kats. } \\
\text { Kurtosis } \\
\text { coef. }\end{array}$ & -0.97 & 0.6 & 2.96 & -1.04 & -0.10 & -1.47 & -0.50 & -0.06 \\
\hline
\end{tabular}

Brokoli ve pırasa yaprakları $\mathrm{Fe}, \mathrm{Cu}, \mathrm{Zn}$ ve $\mathrm{Mn}$ içerikleri Çizelge $5^{\prime}$ de verilmiştir. Brokoli bitkilerine ait yaprak demir içerikleri; 63 - $198 \mathrm{mg}$ $\mathrm{kg}^{-1}$ arasında saptanmıştır. Bu verilere göre, incelenen bahçelerin yaklaşık \% 77'sinin demirce yeterli (70-300 $\mathrm{mg} \mathrm{kg}^{-1}$ ) beslendiği görülmektedir (Kacar ve İnal, 2008; Kacar, 2014). Pırasa yapraklarının demir içerikleri ise $50-298 \mathrm{mg} \mathrm{kg}^{-1}$ arasında değişim göstermiştir. Pırasa bitkisi yapraklarında olgunluk dönemi için farklı araştırıcılar tarafından bildirilen yaprakta demir yeterlilik düzeylerine $\left(60-300 \mathrm{mg} \mathrm{kg}^{-1}\right.$ ) (Kacar ve İnal, 2008; Kacar, 2014) göre incelenen pırasa bahçelerinin yaklaşık \% 60'ı demirce yeterli durumdadır. 
Brokoli bitkilerine ait yaprak çinko içerikleri, 27 - $124 \mathrm{mg} \mathrm{kg} \mathrm{kg}^{-1}$ arasında değişim göstermiştir (Çizelge 5). Kacar ve İnal (2008), brokoli bitkisinde baş oluşum döneminde yaprakta çinkonun yeterli miktarlarının 35 - $200 \mathrm{mg} \mathrm{kg}^{-1}$ arasında olduğunu bildirmişlerdir. Buna göre, yöredeki brokoli bahçelerin yaklaşık \% 67'si çinko bakımından yetersizdir. Pırasa yapraklarının çinko içerikleri ise 22 - $95 \mathrm{mg} \mathrm{kg}^{-1}$ arasında bulunmuştur. Farklı araştırıcılar, pırasa bitkisi yapraklarında olgunluk dönemi için bildirilen yeterli çinko miktarlarının; 25 - $100 \mathrm{mg} \mathrm{kg}^{-1}$ arasında olduğunu bildirmişlerdir (Kacar ve İnal, 2008; Kacar, 2014). Buna göre, incelenen pırasa bahçelerinin yaklaşık \% 40'ı çinko bakımından yetersizdir.

Brokoli bitkileri yaprak bakır içerikleri; 4.40 $16.4 \mathrm{mg} \mathrm{kg}^{-1}$ arasında değişim göstermiştir. Kacar (2014), brokoli bitkisinde baş oluşum döneminde bakıın yeterli miktarını 4 - 15 mg kg ${ }^{-1}$ olarak bildirmiştir. Brokoli bitkisi yapraklarında bildirilen bakır yeterlilik düzeylerine göre, yöredeki brokoli bahçelerin tamamı bakırca yeterli durumdadır (Çizelge 5). Pırasa yapraklarının bakır içerikleri ise 20 - $36 \mathrm{mg} \mathrm{kg}^{-1}$ arasında tespit edilmiştir. Kacar ve Inal (2008) ile Kacar (2014), pırasa bitkisinin olgunluk döneminde yapraklarda yeterli bakır miktarlarının 15-35 mg $\mathrm{kg}^{-1}$ olduğunu bildirmişlerdir. Buna göre; incelenen pırasa bahçelerinin tamamının bakırca yeterli düzeyde beslendiği saptanmıştır (Çizelge 5).

Brokoli ve pırasa bitkilerinin yaprak mangan kapsamları sırasıyla; 26 - $78 \mathrm{mg} \mathrm{kg}^{-1}$ ve 100-195 $\mathrm{mg} \mathrm{kg}^{-1}$ arasında değişim göstermiştir. Farklı araştırıcılar, brokoli bitkisinde baş oluşum döneminde yaprakta manganın yeterli sınır değerlerinin 25 - $200 \mathrm{mg} \mathrm{kg}^{-1}$ pırasada ise $50-250$ $\mathrm{mg} \mathrm{kg}^{-1}$ arasında (Kacar ve İnal, 2008; Kacar, 2014) olduğunu bildirmişlerdir. Bildirilen yeterlilik düzeylerine göre, yöredeki brokoli bahçelerin tamamı manganca yeterlidir (Çizelge 5).

Makro elementlere benzer olarak, her iki bitki çeşidine ait yaprakların mikro element $(\mathrm{Fe}, \mathrm{Cu}, \mathrm{Zn}$, $\mathrm{Mn})$ içerikleri, ait oldukları topraklardaki elementlerin alınabilir miktarları ile uyumludur.

\section{Bitki Örneklerinin Kükürtlü Aminoasit lç̧erikleri}

Brokoli ve pırasa bahçelerinden alınan bitki örneklerinin kükürtlü aminoasit (sistein ve methionin) içerikleri Şekil 1'de verilmiştir.

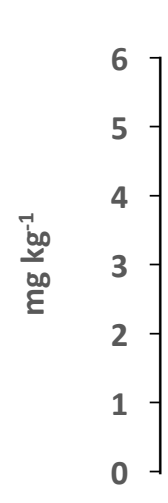



Brokoli

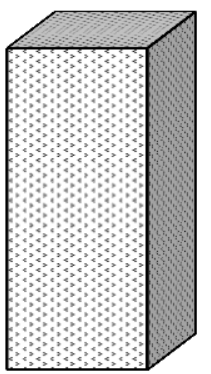

is

Şekil 1. Brokoli ve Pırasa Bitkilerine İlişkin Sistein ve Methionin Miktarları

Figure 1. Cysteine and Methionine Contents of Broccoli and Leek Plants

Şekilden de görüleceği üzere, brokoli bitkilerinin baş örneklerinde ortalama sistein ve methionin miktarları sırasıyla; $5.63 \mathrm{mg} \mathrm{kg}^{-1}$, ve $4.65 \mathrm{mg} \mathrm{kg}{ }^{-1}$ olarak bulunmuştur. Ramirez ve Whitaker (1999), yaptıkları bir çalışmada, brokolide sistein miktarını $5.63 \mathrm{mg} \mathrm{kg}^{-1}$, methionin miktarını ise $4.63 \mathrm{mg} \mathrm{kg}^{-1}$ arasında belirlemişlerdir.
Farklı çalışmalarda brokoli bitkisinde benzer değerler elde edilmiştir (Ukai ve Sekiya, 1999). Pırasa örneklerinde ortalama sistein ve methionin içerikleri ise sırasıyla $5.26 \mathrm{mg} \mathrm{kg}^{-1}$ ve $4.70 \mathrm{mg} \mathrm{kg}^{-1}$ olarak bulunmuştur. Eppendorfer ve Eggum (1996) tarafından yapılan bir çalışmada, pırasa bitkisinde sistein miktarları $5.63 \mathrm{mg} \mathrm{kg}$, 
methionin miktarları ise $4.63 \mathrm{mg} \mathrm{kg} \mathrm{kg}^{-1}$ olarak belirlenmiştir. Çalışmamızdan elde edilen bulgular ile diğer araştırmacılar tarafından bildirilen verilerle karşılaştırıldığında, birbirleriyle uyumlu oldukları görülmektedir.

\section{Bitkilerin Besin Elementleri ile Aminoasit Miktarları Arasındaki ilişkiler}

Brokoli ve pırasa bitkilerinin besin elementi içerikleri ile aminoasit miktarları arasındaki ilişkilere ait korelasyon katsayıları Çizelge 6'da verilmiştir. Brokoli bitkisinin yaprak $\mathrm{K}, \mathrm{Ca}$ ve $\mathrm{S}$ içerikleri ile sistein ve methionin içerikleri arasında pozitif ilişkiler; buna karşın yaprak $\mathrm{P}, \mathrm{Mg}$, $\mathrm{Fe}, \mathrm{Zn}, \mathrm{Cu}$ ve $\mathrm{Mn}$ miktarları ile ise negatif ilişkiler belirlenmiştir. Brokoli bitkisi yaprak $\mathrm{N}$ içerikleri ile amino asit içerikleri arasında herhangi bir ilişki bulunmamıştır. Pırasa bitkisinin ise söz konusu yaprak besin elementleri ile amino asit içerikleri arasında herhangi bir ilişki tespit edilmemiştir. Incelenen iki bitki çeşidinin yaprak besin elementleri ile bitki amino asit içerikleri arasındaki ilişkilerin farklı çıkmasının, tüketilen kısımlarının (amino asit analizi yapılan kısımlarının) farklı olmasından kaynaklanabileceği düşünülmektedir.

Çizelge 6. Bitki Besin Elementleri ile Aminoasit Miktarları Arasındaki iliş̧kiler

Table 6. The Relationships Between Plant Nutrients and Amino Acids Contents

\begin{tabular}{|c|c|c|c|c|}
\hline \multirow{2}{*}{$\begin{array}{l}\text { Besin Elementi } \\
\text { Nutrient Element }\end{array}$} & \multicolumn{2}{|c|}{$\begin{array}{l}\text { Brokoli } \\
\text { Broccoli }\end{array}$} & \multicolumn{2}{|c|}{$\begin{array}{l}\text { Pırasa } \\
\text { Leek }\end{array}$} \\
\hline & $\begin{array}{l}\text { Sistein } \\
\text { Cysteine }\end{array}$ & $\begin{array}{l}\text { Methionin } \\
\text { Methionine }\end{array}$ & $\begin{array}{l}\text { Sistein } \\
\text { Cysteine }\end{array}$ & $\begin{array}{l}\text { Methionin } \\
\text { Methionine }\end{array}$ \\
\hline $\mathrm{N}$ & 0.679 ö.d & 0.715 ö.d & 0.174 ö.d & 0.066 ö.d \\
\hline$P$ & $-0.708 * *$ & $-0.750 * *$ & 0.191 ö.d & 0.056 ö.d \\
\hline K & $0.701 * *$ & $0.773 * *$ & 0.200 ö.d & 0.292 ö.d \\
\hline $\mathrm{Ca}$ & $0.723 * *$ & $0.747 * *$ & 0.322 ö.d & 0.260 ö.d \\
\hline $\mathrm{Mg}$ & $-0.647 * *$ & $-0.676 * *$ & 0.129 ö.d & 0.175 ö.d \\
\hline $\mathrm{S}$ & $0.786 * *$ & $0.758 * *$ & 0.050 ö.d & 0.042 ö.d \\
\hline $\mathrm{Fe}$ & $-0.687 * *$ & $-0.728 * *$ & -0.219 ö.d & -0.149 ö.d \\
\hline $\mathrm{Zn}$ & $-0.439 *$ & $-0.492 *$ & -0.092 ö.d & -0.203 ö.d \\
\hline $\mathrm{Cu}$ & $-0.440 *$ & $-0.495^{*}$ & 0.178 ö.d & 0.208 ö.d \\
\hline $\mathrm{Mn}$ & $-0.440^{*}$ & $-0.483^{*}$ & 0.161 ö.d & 0.076 ö.d \\
\hline
\end{tabular}

*: $p \leq 0.05 ; * *: p \leq 0.01 ;$ ö.d: Önemli değil

Sebzelerin amino asit içeriklerinin belirlenmesi ile ilgili çalışmalar son derece sınırlıdır. Ancak farklı araştırıcıların farklı bitkilerin aminoasit içerikleri ile bitki besin maddesi içerikleri arasındaki ilişkileri belirlemeye yönelik yaptıkları çalışma sonuçları, araştırmamızda elde ettiğimiz sonuçlar ile uyumludur.

Wang ve Daun (2006), baklagillerin aminoasit kompozisyonu, mineral madde miktarı, kimyasal bileşimi üzerine çevresel faktörlerin etkisi ile protein içeriğine çeşit etkisini belirlemek amacıyla yaptıkları çalışmada; bitkilerin mangan, fosfor ve çinko içeriklerinin, protein içerikleri ile negatif bir ilişki içinde olduğunu bildirmişlerdir.

Adak (2009), mercimek bitkisinde kükürtlü gübrelemenin aminoasit miktarına etkisini araştırdığı çalışmasında, kükürt uygulamalarıyla aminoasit miktarının arttığını, en yüksek sistein miktarının yüksek kükürt uygulamasında $(0.136 \mathrm{~g}$ $/ 100 \mathrm{~g})$; en yüksek methionin aminoasit miktarının da $0.279 \mathrm{~g} / 100 \mathrm{~g}$ kükürt uygulamasında elde edildiğini bildirmiştir.

Byers ve Bolton (1979), kükürt uygulanan topraklarda yetiştirilen buğday bitkisi tanelerinde methionin ve sistein miktarlarının artış gösterdiğini bildirmişlerdir.

\section{Sonuç ve Öneriler}

Bu çalışmada, kükürt içeriği yüksek olduğu bilinen brokoli ve pırasa bitkilerinde, kükürtlü amino asitlerden sistein ve methionin miktarları ile besin elementleri arasındaki ilişkiler belirlenmiştir. Elde edilen sonuçlara göre; yöre toprakları genel olarak; hafif alkalin tepkimeli, kireçli, hafif bünyeli ve organik maddece fakirdir. 
Yörede yetiştirilen brokoli bitkilerinin \% 50'i pırasa bitkilerinin ise yaklaşık \% 43'ü kükürtçe yetersizdir. Bu bağlamda; yöre topraklarının yüksek kireç içeriklerine bağlı oluşan alkali toprak reaksiyonlarında çözünemez forma geçen bazı besin elementlerinin alınımını arttırmak için kontrollü olarak toz kükürt kullanılması ve bünyelerinin hafif, organik madde içeriklerinin düşük olması nedeniyle de topraklarda düzenli periyotlarda organik gübre kullanılması önerilebilir.

Sebzelerin amino asit içerikleri ile besin elementleri içerikleri arasındaki ilişkileri belirlemeye yönelik araştırmaların sınırlı olması nedeniyle farklı ekolojilerde farklı bitki çeşitleri ile benzer çalışmaların yapılmasının yararlı olacağı düşünülmektedir.

\section{Kaynaklar}

Açıkgöz, N., Akkaş, Monghaddam, M.E. A.\& Özcan, K. (1993). TARIST PC ler İçin İstatistik ve Kantitatif Genetik Paketi. Uluslararası Bilgisayar Uygulamaları Semp. 19 Ekim 1993, s. 133, Konya.

Adak, S. (2009). Farklı Hasat Zamanları ve Kükürt Gübrelemesinin Mercimeğin (Lens culinaris Medik.) Aminoasit Bileşimine Etkisi. Ankara Üniversitesi Bilimsel Araştırma Projeleri. No: 20070711003 HPD

Akalan, İ. (1965). Toprak Oluşu, Yapısı ve Özellikleri. Ankara Üniv. Ziraat Fak. Yay. No: 231, $332 \mathrm{s.}$

Anonim. (1993). Soil Survey Manual, Soil Survey Division Staff. United States Department of Agriculture, Handbook No:18, U.S. Government Printing Office, Washington, D.C, USA. p. 410.

Anonim. (2002). Brokolinin Ülsere Etkisi. Hasat Dergisi Kasım 2002 s:27.

Bouyoucous, G.D. (1951). A recalibration of the hydrometer method for making mechanical analysis of the soil. Agronomy Journal, 43, pp. 434-438.

Bozokalfa, M. K., Uğur, A., Kavak, S., Eşiyok, D. \& Yağmur, B. (2003). Çinko sülfat Uygulamalarının Brokolide Verim Kalite ve Mineral Madde Miktarı Üzerine Etkisi. Türkiye IV. Ulusal Bahçe Bitkileri Kongresi, 08 Eylül 2003, Antalya.

Bremmer, J.M. (1965). Total Nitrogen, Editor C. A. Black, Methods of Soil Analysis Part II. American Society of Agronomy Inc., Publisher Madison, Winconsin, USA, P:1149-1178.

Byers, M. \& Bolton, J. (1979). Effects of nitrogen and sulphur fertilizers on the yield, $\mathrm{N}$ and $\mathrm{S}$ content, and aminoacid composition of grain of spring wheat. Journal of Science of Food and Agriculture 30: 251263

Eppendorfer, W.H. \& Eggum, B.O. (1996). Fertilizer effects on yield, mineral and amino acid composition, dietary fibre content and nutritive value of leeks.
Plant Food for Human Nutrition 49:163-174 (February 1996) 1996 Kluwer Academic Publishers. Printed in the Netherlands.

Eşiyok, D. (1996). Bornova Koşullarında Yetiştirilmeye Uygun Brokoli Çeşitlerinin Belirlenmesi Üzerine Bir Araştırma. Ege Üniversitesi Ziraat Fakültesi Dergisi. 33(1):55-62. Bornova-izmir.

Evliya, H. (1960). Kültür Bitkilerinin Beslenmesi. Ankara Üniv. Ziraat Fak. Yay. No: 36, 656s.

FAO, (1990). Micronutrient, Assessment at the Country Level: An International Study. FAO Soil Bulletin by Sillanpaa, Rome.

Fawzi , A.F.A. \& El-Fouly, M.M. (1980). Soil and Leaf Analysis of Potassium in Different Areas in Egypt. Role of Potassium Crop Production, pp. 73-80, IPI, Bern.

Fox, R.L., Olson, R.A. \& Rhoades, H. F. (1964). Evaluating the sulphur status of soils by plants and soil tests. Soil Sci. Soc. Amer. Proc. 21:287-292.

Jackson, M.L. (1967). Soil Chemical Analysis. Univ of Nebraska, College of Agriculture, Dept. of Argon, Nebraska, USA.

Kacar, B. (1984). Bitki Besleme Uygulama Kılavuzu. Ankara Üniv. Zir. Fak. Yay. No: 900.

Kacar, B. (1995). Bitki ve Toprağın Kimyasal Analizleri. III. Toprak Analizleri. Ankara Üniv. Zir. Fak. Eğt. Araş. ve Gel. Vakfı Yay. No: 3, Ankara. 705s.

Kacar, B. \& Inal, A. (2008). Bitki Analizleri. Nobel Yayın No: 1241.

Kacar, B. (2009). Toprak Analizleri. Nobel Yayın No: 1387.

Kacar, B. (2014). Kolay Uygulanabilir Bitki Analizleri. Bitki Toprak ve Gübre Analizleri 2, Nobel Yayın No: 910.

Kellog, C. E. (1952). Our Garden Soils. the Macmillian Company. New York. Pages 232.

Lindsay, W. L. \& Norvell, W. A. (1978). Development of A DTPA Soil Test for Zinc, Iron, Manganese and Copper. Soil Science of America, 42: 421-428.

MEGEP, Bahçecilik. (2013). Pırasa Yetiştiriciliği. TC. M.E.B. Mesleki Eğitim ve Öğretim Sistemini Güçlendirme Projesi. http://www.megep.meb.gov.tr/ Erişim tarihi: Aralık 2016.

Mustafa, A., Aman, P., Andersson, R. \& Eldin, A. K. (2007). Analysis of free amino acids in cereal products. Food Chemistry, V: 105, I: 1.

Olsen, S. R., Cole, C.V., Watanabe, F.S. \& Dean, L.A. (1954). Estimation of available phosphorus in soils by extraction with sodium bicarbonate. United States Department of Agriculture; Washington.

Pratt, P. F. (1965). Potassium. Editor C. A. Black, Methods of Soil Analysis Part II. American Socienty of Agronomy Inc., Publisher Madion, Winconsin, USA, pp. 1022.

Ramirez, E.C. \& Whitaker, J.R. (1999). Purification and Characterization of Sistein Lyase from Broccoli. J. Agric. Food Chem., Vol. 47, No: 6.

Reuter, D. \& Robinson, J. B. (Eds.), (1997). Plant analysis: an interpretation manual. CSIRO publishing.

Salunkhe, D.K. \& Kadam, S.S. (1998). Handbook of vegetable science and technology: Production, composition, storage and processing. p. 721, Marcel Dekker, New York ISBN 0-8247-0105-4.

Schlichting, E. \& Blume, H.P. (1966). Bodenkundliches Praktikum. Verlag Paul Parey. Hamburg- Berlin.

Scott, N. M., Dyson, P. W., Ross, J. \& Sharp, G. S. (1983). Response of grassland to the application of sulphur 
at two sites in NE Scotland. J. Sci. Food Agric., 34:357-361.

TÜiK, 2016. Bitkisel Üretim İstatistikleri. Türkiye İstatistik Kurumu, https://biruni.tuik.gov.tr/bitkiselapp/bitkisel.zul Erişim: Aralık 2018.

Ukai, K. \& Sekiya, J. (1999). Rapid purifcation and characterization of sistein lyase $b$ frombroccoli inflorescence. Phytochemistry, (51) 853-859.

U.S. Soil Survey Staff. (1951). Soil Survey Manuel. Agriculture Research Administration. U.S. Dept. Agri., Handbook, No: 18.

Ünsal, A.S. \& Hayoğlu, G. (2018). The effects of canning process on the properties of marathon and sultan varieties of broccoli. Harran Tarım ve Gıda Bilimleri Dergisi, 22(3): 420- $430 . \quad$ DOI: $10.29050 /$ harranziraat.4058 63
Wielebski, F. (2015). The Role of Sulphur As a Factor Affecting Quantity and Quality of Yield of Winter Oilseed Rape. Oilseed crops, 36: 39-59.

Yoldaş, F. \& Eşiyok, D. (2004). Dikim Sıklığı, Ekim ve Dikim Zamanlarının Brokoli'de Verim ve Kalite Parametreleri Üzerine Etkileri. Ege Üniv. Ziraat Fak. Derg., 2004, 41 (2):37-48.

Wang, N. \& Daun, J. K. (2006). Effects of variety and crude protein content on nutrients and anti-nutrients in lentils (Lens culinaris). Food Chemistry, 95 (3): 493502.

Zengin, M. (2012). Toprak ve Bitki Analiz Sonuçlarının Yorumlanmasında Temel ilkeler. In: Bitki Besleme (Ed. Karaman, M.R.), Gübretaş Rehber. 